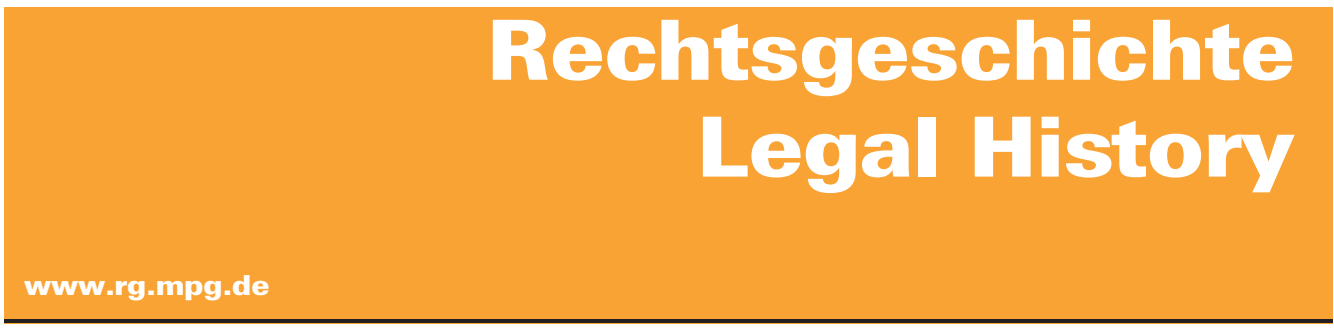

http://www.rg-rechtsgeschichte.de/rg24

$\operatorname{Rg} 242016 \quad 380-386$

Zitiervorschlag: Rechtsgeschichte - Legal History Rg 24 (2016)

http://dx.doi.org/10.12946/rg24/380-386

Monica Stronati

\title{
The History of Social Law in Italy: Some Considerations
}




\section{Monica Stronati}

\section{The History of Social Law in Italy: Some Considerations}

1 Yesterday: social laws have no legal status

The first social laws in Italy were a few faint measures implemented by the liberal State to cope with the labor question. Some examples are the law on the labor of women and children, the legal recognition of workers' mutual aid societies, voluntary insurance coverage against injuries at work, the civil liability of owners, the establishment of arbitrators' colleges, the institution of compulsory insurance coverage, and the special maternity fund. There is, however, certainly a close connection with the labor question: "The labor law discipline in Italy was established not against, but within the traditional boundaries of private law «. ${ }^{\mathbf{1}}$

The true constitutional expression of the liberal State coincides with legislative codification, especially that of civil law. The legal model is FrenchNapoleonic, pivoting on the equality of the citizenowners. Nineteenth-century legal thought owes much to the principles stemming from the French Revolution, particularly freedom and equality: "Men are born and remain free and equal in rights «. ${ }^{2}$ However, the universal principle of equality is based on the "mechanism of reciprocity «, ${ }^{3}$ where equal liberty implies mutual respect for one another's liberties. This principle influences the construction of the legal system, particularly the great importance given by the civil codes to the "schéma contractuel,${ }^{\mathbf{4}}$ as in the free encounter of the wills of parties that are supposed to be equal. Any other alien element, apart from what has been freely agreed upon by the individual contractors, would constitute a violation of their individual liberty. This individualistic model leaves no room for collective aggregation and also affects the treatment of the mass phenomenon of poverty, which is addressed, as it were, as an individual problem of each single worker. The same vision affects the institution of social insurance systems, in which people help themselves through payment of national insurance premiums. The same applies to all contemporary literature on "self-helpism «, the folk ideology in which relief from poverty is always connected to an individual path of education and hard work. This vision corresponds with the legal representation of society and of the relations between individuals, and it captures the actual legal status of the citizen non-owner.

Since the Enlightenment, law is to be rational. The goal of writing codes is legal certainty, but real life is expunged in the process, and this condemns the codes to remain at an unbridgeable distance from people's lives. ${ }^{5}$

Legal science merely plays the role of a guardian of the law, and it omits the social and economic context of work from dogmatic speculation. The most insightful legal scientists ascertain the weakness of individuals in the legal code. Particularly the paradigmatic figure of the laborer is completely absent in the code. This "gap« justifies their request for State intervention in the face of injustices generated by the negotiating freedom granted to parties that are mistakenly presumed equal. The State has to intervene because it is considered as the friendly force working for both parties, or even as the only subject able to balance the contracting parties' forces and act as a guarantor of the common interest. ${ }^{6}$

So social awareness overlaps with individualism; the former should have changed the features of private law, leading to a completely different organization of the whole private law system. Only a minority of Italian legal scientists questioned the value attributed to the social laws, particularly Law n. 80 of 17 March 1898 on compulsory insurance
1 Cazzetta (1988) 156. All translations are by the author.

2 Art. 1, Déclaration des droits de l'homme et du citoyen, 1789.

3 Art. 4 Déclaration des droits de l'homme et du citoyen: "Liberty consists in the freedom to do every- thing which injures no one else; hence the exercise of the natural rights of each man has no limits except those which assure to the other members of the society the enjoyment of the same rights. These limits can only be determined by law«.

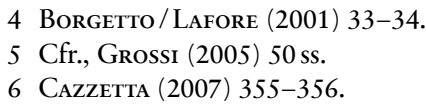

4 Borgetto/Lafore (2001) 33-34.

5 Cfr., Grossi (2005) 50 ss.

6 Cazzetta (2007) 355-356. 
against accidents at work for laborers, which undermined a central principle of the legal code: the relationship of cause and effect between accountability and fault. The "new law», drafted outside the code, should have been deemed a special law, not an exceptional law, and should have been subject to broad interpretation. However, "Social laws were not extended by means of interpretation, and did not determine conflicts in the civil law system ". ${ }^{7}$ In other words, the myth of the sovereign State affects the innovators too: they do not go beyond generic requests for legislative intervention through social laws, and in the most daring examples they theorize a recodification of the private-social law. ${ }^{8}$ The common law remains untouched and lawmakers prefer to promulgate the first social laws. These can be interpreted as achievements of the socialist movements only indirectly and ambiguously. In fact, they are rather the result of anti-socialist policies. The invention of national insurance systems has been the response of nation-states to the conflict between property and livelihood, that is, a strategy to manage poverty and social exclusion.'

The link between work and social laws mainly lies in the identification of the "new « nineteenth century poverty with laboring pauperism: a problem of liberal governments to be solved through State intervention. Therefore, jurists reduce social laws to special and transient interventions, thus considering them more as political measures and not "authentically« legal. The need to preserve the common law jeopardizes the legal nature of the social laws. In essence, two parallel systems coexist: public and private law, socio-economic and legal rationale, social laws and the civil law code.

This original verdict restricted genuine legal interest only to labor law, which, however, as mentioned above, was born in opposition to the intrusion of social legislation that was perceived as a threat to the dogmatic certainties of the code system. The term "social legislation" in common speech may coincide with "social welfare«, which has some basis in legislative action in that the social security law has gained autonomy. Jurisprudence of labor law has shown little interest in the welfare sector, whose study was said, in the fifties, to be in decay:

»Overall, the legal literature was a poor production, especially as regards quality, because, apart from for some isolated exceptions, it was limited to presenting the laws published in such matters, possibly showing their evolution, or at the most faced scientific and perhaps topical problems, but, however, never opened to questioning the foundations ${ }^{\mathbf{1 0}}$

The legal essays on welfare legislation are fragmentary. A systematic study does not exist and, when surveying the few monographs, they do not go beyond the mere chronological breakdown of the social laws, ${ }^{\mathbf{1 1}}$ often compiled by public officials for teaching purposes or targeted at legal professionals.

On one hand, labor law, taught for decades as a specialist course, is now disappearing as a teaching assignment from the educational system. On the other hand, a revival of the seventies and eighties is now taking place in academia. This revival in fact only incidentally relates to the social laws, as in this case, the main topic is not surprisingly the socialist law studies movement.

The socialist law studies movement yielded only "modest men and modest results". However, its merit was to have contributed a critical voice to jurisprudence:

»(the movement) was not vocationally subversive, nor did it develop an alternative model of society; it only aimed, with diversity of tones and objectives according to the various authors, to break the monolith of a bourgeois legal heritage that $[\ldots]$ seemed, in the late nineteenth century, a cult object more than a field for discussion and possible revision ${ }^{\mathbf{1 2}}$

Without naively pretending to be exhaustive, we can, therefore, initially assume that legal science did not give birth to a discipline with social legis-
7 Cazzetta (1988) 164.

8 Stronati (2012)

9 SANTORO $(2013) 74$

10 Persiani (2010) 8-9.

11 Levi SANdri (1942); Sellin (1971); Martone (1974/1975); Monteleone
(1974); MONTELEONe (1976); Marucco (1981); Jocteau (1982); SCALDAFERRI (1986); SCALDAFERRI (1986); Gozzi (1984); CazzetTa (1988); Rizzo (1988); GuSTAPANE (1989); Cazzetta (1991); Ritter
(1996); Bartocci (1999); Melis (2000); Silei (2003); Silei (2004); Marchetti (2006); Passaniti (2008); Passaniti (2011); Contigiani (2012); Stronati (2014a); Stronati (2014b).

12 Grossi (1974-1975) 2. 
lation as its object, a theme taken up by institutional historians, by historians in general, and absorbed by history of the welfare state.

2 Today: the »crisis« of the welfare state

The welfare state is a public policy system designed to guarantee citizens, from cradle to grave, basic welfare standards such as health, education, nutrition, housing and income. However, the space for State intervention in such areas seems to have reached its limit, so much so that public services are becoming increasingly inefficient, and it is almost impossible to pass new expenditures or expand the existing administrative system.

It is widely argued that the welfare state is in deep crisis. This is certainly a complex issue also due to large demographic changes and economic choices taken in the international market, among others, which I am not qualified to assess. Still, the question should not be reduced merely to a State's financial capacity or to miraculous economic formulas chasing an increasingly dynamic global market. Indeed, the system in question was fully established after the Second World War, which was a moment of deep global crisis.

Therefore, we can talk of welfare state crisis for a given definition of "crisis«, i.e. the meaning of change and choice. Indeed, "crisis" means here opportunity to rethink the idea of society and State, and consequently to rethink the role of the latter in social policies. In other words, every experience of State organization is the bearer of a specific idea of public policies and social rights.

From this viewpoint, before talking about the welfare state in crisis, we should deal with the crisis of sovereignty of nation-states. The same principle of fraternity originates as an abstract and universal concept, though it has flourished in the very real dimension of the nation-states. The design of the welfare system in Europe, too, is based on the close connection between wealth and national territory. This was indeed a fortunate combination at the times of the Fordist production, when the interests of State, businesses, and citizens' needs could be more easily balanced. After that time it became an outdated concept, if only because the interest of business is to move freely in international markets, and the interest of citizens is to get better products and a wider margin of decision in local self-government. Consequently, redistribution is no longer »the exclusive task of the State which must take action when all is done, as then we would, inertly and hypocritically sad, assist to increasing inequality. On the contrary, action must also be taken at the moment of wealth production ${ }^{13}{ }^{13}$ Social solidarity cannot be realized solely by the State, »the recipient of all the expectations and, because of this, increasingly unable to adequately respond to them «. ${ }^{14}$ Rather, the role of the government should be that of a "coordination center of groups that spontaneously emerge from societal dynamics «, ${ }^{15}$ or responsible for »shared administration « with civil society, whose autonomy and responsibility it recognizes. ${ }^{\mathbf{1 6}}$ Therefore, corporate social responsibility should be strengthened and, above all, all the living forces in society should be mobilized in order to escape the State / market dichotomy and to give greater importance to citizen organizations, because »The fate and effectiveness of democracy did not play only through the mechanisms of the parliamentary representative democracy or through the mediation of an administration responsible for the public interest, but also (in the first place?) in the proliferation of associative public spaces ${ }^{17}{ }^{17}$

Despite appearances, the crisis of the welfare state cannot be inferred strictly by economic and financial analysis. Rather, there are social and cultural boundaries: »The real question behind the future of the welfare state is the future of society itself«. The underlying question is how society will evolve, "how does the State transform society, what shape does it give to the relationships between individuals «? ${ }^{\mathbf{1 8}}$

Ultimately, the reason for the "crisis" of the welfare state lies »in the same process of generation of the modern nation-state", particularly in the representation of society and nation-state depicted

13 Bruni / Zamagni (2004) 19.

14 Costa (2009) 63.

15 Costa (2009) 63.

16 Bruni / Zamagni (2004) 238-239.

17 Caillé/Laville (1998) 13.

18 Rosanvallon (1994) 16. 
in the reference literature. The real convergence of the welfare state crisis would therefore be "the relationship between State and citizen (as has been built along the entire parabola of modernity)«. This is exactly what we should reconsider:

»the belief that social solidarity can be channeled by the State only, as if no intermediate entities existed between State and citizen. This assumption, typical of the liberal State, proudly supporting the healthy and final demolition of any intermediate entities by means of revolution, remains substantially unchanged even in the phase of construction and realization of the welfare State, and is now showing all its fragility ${ }^{19}$

The »crisis« of sovereignty necessitates a new and different perspective because social bonds and solidarity do not depend solely on the State action, but also owe much to the spontaneous initiative of a society's members:

"Based on this assumption, we can rethink the traditional welfare state by relying on a recent phenomenon: the growing importance of what has been called the third sector of civil society, which is sthird with respect to the State and to the market, because it includes organizations and activities not attributable either to the action of the former nor to the logic of the latter ${ }^{20}$

The civil associations' world basically forces us to abandon the State / market dichotomy and rediscover traditions that history had discarded. On one hand, it is true that, as a definition, the third, or non-profit, sector has emerged only recently. Nevertheless, it has in essence been an important part of European culture, even in regulation, if by third sector we mean:

»those entities that are different from the market and from the State, and act in a sphere of action that is not totally sprivate but not even comparable to the spublic . They do not pursue a particular interest, but at the same time cannot be acknowledged as a surrogate of the public institutions. In this sense there always has been, in Italy, a sthird sector<, although only recently it has been well defined following on from a mainly English-based reference literature ${ }^{\mathbf{2 1}}$

The golden century of associations was the 19th, which "will go down in history as the century of associations «. ${ }^{22}$ We must go back to the origins of the welfare state that "has its roots in that late nineteenth-century common language of solidarity that (although made of different theoretical idioms) claim[ed] the overcoming of individualism and a greater involvement of the State in the government of society «. ${ }^{23}$ In this period of liberal societies, solidarity was realized through mutual aid societies. ${ }^{24}$ This time was a historical deviation that, however, today should be looked at in a different light as a phenomenon whose effects are measured in the long run and that perhaps deserves more attention in historical perspective. Firstly, this phenomenon is to be studied for its own sake and not "as a step toward transitional forms of more combative labor action« to avoid obscuring important aspects of society. Significantly, mutual aid societies are not limited to concretely improving the fortunes of part of the population. Rather, they »inspire a veritable spirit of independence and democracy in the social fabric, whatever the original intentions of their founders « ${ }^{25}$ In other words, we require an approach that does not see
19 Costa (2009) 61-62.

20 Costa (2009) 62.

21 Rossi/Zamagni (2011) 13.

22 Groppali (1914) 226.

23 Costa (2009) 32-33.

24 Rossi (2013) 811.

25 Gibaud (1986) 13; 37-38. In Italy

»Historians have been inclined to view the effort by liberal elites to form popular associations, before and after unification, as a half-hearted and short-lived prologue to the prolifera- tion of truly independent, social trade unions. There are good reasons, however, to put aside the long view of popular associations as failed instruments of bourgeois hegemony or modern labor organization, and examine more closely what was new and meaningful about them in the specific context of Italian unification. Italian liberals were not united in their enthusiasm for popular associations, but this is neither surprising nor sufficient to explain historians' relative neglect of the topic «, SOPER (2013) 12-13. 
conflict as a category to understand the phenomenon of mutual aid societies. Mutual aid associations were born as a spontaneous means to limit liberalism and, in many respects, as a long-term project aimed at dismantling the capital-labor class relation in the capitalist system.

\section{Tomorrow: more society, less State}

The mutual aid association system values the citizen-member, an interesting alternative to the welfare state, where the citizen is a mere user of services offered because of abstractly identified needs, and the welfare mix, where the citizen is a customer. ${ }^{26}$ The mutual aid societies are a modern tool of action for civil society, which self-organizes to respond to the real and concrete needs of communities. This example of State/society relation presents an alternative to an atomistic, individualistic type of relation. This "model $\ll$ is based on self-help, solidarity and democratic participation, and it combines the centrality of the single individual with the need for relations, which are equally necessary for the welfare of individuals. The »one man, one vote " principle does not realize just a formal and abstract equality, but a substantial one among association members by involving them in participation responsible for the vitality of the association. Before being susceptible to claim, social rights must be pursued. Therefore, not only do the mutual aid associations represent a model of social inclusion, but they are also the expression of civil society activism.

Modern associations originated in industrialization and the need to create forms of self-defense against the social risks brought about by deep socio-economic changes. The aims of the associations can be easily expanded and adapted to emerging needs. They often fertilize the growth of other forms of association, such as the cooperative societies of consumers as well as manufacturing and credit unions. The number of mutual aid societies has increased significantly with the granting of the Albertine Statute in a euphoric climate of constitu- tional liberties, ${ }^{27}$ holding great promise for equality rights, freedom of thought, opinion and so on. Such liberties were left without real judicial protection, as the liberal State promoted the sovereignty of statute law and only recognized liberties that were expressly provided by positive law. In that perspective, the constitution is not a legal source superordinate to the positive law, but it is essentially a political compromise and, therefore, does not have the legal power to ensure even the modest liberties declared there. ${ }^{\mathbf{2 8}}$

The mutual aid societies, supported by a minority of the liberal bourgeoisie, break this individualistic vision of the contractual scheme by leveraging self-help principles in a context of relations and not merely of the individual. Self-help that values the individual is realized through the mottos: »there's safety in numbers « or »one for all and all for one«. In this sense, the principle of Selbsthilfe (self-help) does not mean »God (or heaven) helps those who help themselves", but it is better expressed as self-help in the context of mutualist structures ${ }^{29}$

This reference model was developed by SchulzeDelitzsch, who was not surprisingly a lawyer and, from 1837, a magistrate. The project was constitutionally significant, because the final goal is a general »social reform of which the People's Banks would be only one facet ${ }^{30}{ }^{30}$ Liberal reform considers not only the capital, but also the moral aspects, to be key factors.

Individual freedom and strength are always fundamental, but it is free association that represents everyone when the individuals are not strong enough. ${ }^{31}$ The jurist understands that, in order to address people's miseries, the leverage action is economic in nature. Social and constitutional reform is entirely based on associations, particularly on the manufacturing cooperative societies, which must be realized by the means of consumer and credit unions. The German reforms profoundly inspired Italian Luigi Luzzatti, ${ }^{32}$ one of the founding fathers of the cooperative banks in Italy and popularizer of the cooperation model throughout Europe and beyond. ${ }^{33}$ The formula elaborated by

\footnotetext{
26 ZAMAGNi (2012) $11 \mathrm{ss.}$

27 Lacchè (2012) 30 ss.

28 Fioravanti (2009) 44.

29 GuESLIN (1982) 55

30 LeONARDI (2002) 11.

31 LeONARDi (2002) 11.
}

32 Schulze-Delitzsch (1871).

33 Gueslin (1985) 11. 
Luzzatti in order to realize the principle of equality in a substantial, not merely formal, sense of solidarity is to make credit democratic. According to Luzzatti, credit does not create capital, but simply increases capital utility. ${ }^{34}$

The Luzzatti proposal is based on inter-class association, particularly on the link between banks and mutual aid societies. In other words, he argued that access to credit is the instrument to achieve economic equality, which is itself a key to civil and social rights. This, in many respects visionary, project was never achieved. Later, the social security system of the mutual aid societies came into decline and was finally replaced by the universal social protection of state systems. However, the reasons for this "failure s should not be ascribed to the inefficiency of mutual aid societies, but rather to specific political and juridical reasons. The first reason is the myth of national sovereignty. This limit is common to both the liberal and the democratic legal systems, which do not tolerate intermediate and autonomous entities in the State. Forms of association are allowed only as the sum of individual liberties or as forms of decentralization; that is, local State administration that cannot necessarily be equated with »democracy «. ${ }^{35}$ The policies against poverty reveal that the collaboration between State and society was not intended to be a space to develop autonomy, but rather »as a government strategy «. ${ }^{36}$

Moreover, the myth of the absolute State sovereignty drastically simplifies the law by putting topdown authoritative legislation as the only source of law, excluding the bottom-up laws for regulating society, ${ }^{37}$ thus depriving it of an essential instrument of expression.

\section{Bibliography}

- Bartocci, Enzo (1999), Le politiche sociali nell'Italia liberale (1861-1961), Roma

- Borgetto, Michel, Robert Lafore (2001), L’État-providence, le droit social et la responsabilité, in: Lien social et Politiques 46, $31-42$

- Bruni, Luigino, Stefano Zamagni (2004), Economia civile. Efficienza, equità, felicità pubblica, Bologna

- Caillé, Alain, Jean-Louis Laville (1998), Présentation, in: Revue du MAUSS, Une seule solution, l'association? Socioéconomie du fait associatif 11, 5-20

- Cazzetta, Giovanni (1988), Leggi sociali, cultura giuridica ed origini della scienza giuslavoristica in Italia tra Otto e Novecento, in: Quaderni Fiorentini per la Storia del pensiero giuridico moderno 17, 155 ss.

- Cazzetta, Giovanni (1991), Responsabilità aquiliana e frammentazione del diritto comune civilistico (1865-1914), Milano

- Cazzetta, Giovanni (2007), Scienza giuridica e trasformazioni sociali. Diritto e lavoro in Italia tra Otto e Novecento, Milano

- Contigiani, Ninfa (2012), Le origini storiche della legislazione sociale e dell'assistenza pubblica, in: Morzenti-Pellegrini, Remo, Viviana Molaschi (eds.), Manuale di legislazione dei servizi sociali, Torino, 1-39

- Costa, Pietro (2009), Cittadinanza sociale e diritto del lavoro nell'Italia repubblicana, in: Balandi, Gian Guido, Giovanni Cazzetta (eds.), Diritti e lavoro nell'Italia repubblicana, Milano, 21-83

- Fioravanti, Maurizio (2009), Costituzionalismo. Percorsi della storia e tendenze attuali, Roma, Bari

- Gibaud, Bernard (1986), De la mutualité à la sécurité sociale. Conflits et convergences, Paris

- Gozzi, Gustavo (1984), Legislazione sociale e crisi dello Stato di diritto tra Otto e Novecento. Due modelli: Italia e Germania, in: Annali dell'istituto storico italo-germanico in Trento, X, 195 ss.

- Groppali, Alessandro (1914), I fondamenti giuridici del solidarismo, Genova

- Grossi, Paolo (1974-1975), Pagina introduttiva, in: Quaderni Fiorentini per la Storia del pensiero giuridico moderno: Il "Socialismo giuridico«. Ipotesi e letture, I, 1-4

- Grossi, Paolo (2005), Mitologie giuridiche della modernità, Milano

- Grossi, Paolo (2006), Società, diritto, Stato. Un recupero per il diritto, Milano

- Gueslin, André (1982), Le Credit Mutuel. De la Caisse rurale à la Banque sociale, Strasbourg

- Gueslin, André (1985), Les fondateurs de la banque coopérative, in: La Revue de l'économie sociale, L'épargne populaire, 5, juillet-septembre, 7-15

34 Luzzatti (1863) 19.

35 MANnORI (2014) 65 ss.; Sordi (2014)

135 ss.

36 Procacci (1998) 24-25.

37 Grossi (2006) 203 ss. 
- Gustapane, Enrico (1989), Le origini del sistema previdenziale: la Cassa nazionale di previdenza per l'invalidità e la vecchiaia degli operai (19 novembre 1898 - 19 luglio 1919), in: Novant'anni di previdenza in Italia: culture, politiche, strutture. Atti del Convegno. Roma 9-10 novembre 1988, supplemento al n. 1 di Previdenza sociale, Roma

- Jocteau, Gian Carlo (1982), Le origini della legislazione sociale in Italia. Problemi e prospettive di ricerca, in: Movimento operaio e socialista XXVIII, 289 ss.

- Lacchè, Luigi (2012), Il nome della »libertà . Tre dimensioni nel secolo della Costituzione (1848-1948), in: Bambi, Federigo (ed.), Un secolo per la Costituzione (1848-1948). Concetti e parole nello svolgersi del lessico costituzionale italiano, Atti del Convegno, Firenze, Villa Medicea di Castello, 11 novembre 2011, Firenze, 30 ss.

- Leonardi, Andrea (2002), L'esperienza cooperativa di F. W. Raiffeisen ed i suoi primi riflessi in area tirolese, Trento

- Levi Sandri, Lionello R. (1942), Istituzioni di legislazione sociale, Milano

- Luzzatti, Luigi (1863), La diffusione del credito e le banche popolari, Padova

- Mannori, Luca (2014), >Autonomiar. Fortuna di un lemma nel vocabolario delle libertà locali tra Francia e Italia, in: Quaderni Fiorentini per la Storia del pensiero giuridico moderno, Autonomia. unità e pluralità nel sapere giuridico fra Otto e Novecento XLIII, 65 ss.

- Marchetti, Paolo (2006), L'essere collettivo. L'emersione della nozione di collettivo nella scienza giuridica italiana tra contratto di lavoro e Stato sindacale, Milano

- Martone, Luciano (1974/1975), Le prime leggi sociali nell'Italia liberale (1883-1886), in: Quaderni Fiorentini per la Storia del pensiero giuridico moderno 3/4, 103 ss.

- Marucco, Dora (1981), Mutualismo e sistema politico. Il caso italiano (1862-1904), Milano

- Meccarelli, Massimo (2011), Diritto giurisprudenziale e autonomia del diritto nelle strategie discorsive della scienza giuridica tra Otto e Novecento, in: Quaderni Fiorentini per la Storia del pensiero giuridico moderno 40, 721-745

- Melis, Guido (2000), Sistemi di tutela: previdenza, assistenza, legislazione sociale, in: Della Peruta Franco, Simone Misiani, Adolfo Pepe (eds.), Il sindacalismo federale nella Storia d'Italia, Roma, 15 ss.

- Monteleone, Giulio (1974), La legislazione sociale al Parlamento italiano. La legge del 1886 sul lavoro dei fanciulli, in: Movimento operaio e socialista XX, 4, 229 ss.

- Monteleone, Giulio (1976), La legislazione sociale al Parlamento italiano. Gli infortuni sul lavoro e la responsabilità civile dei padroni 1879-1885, in: Movimento operaio e socialista XXII, 177 ss.

- Passaniti, Paolo (2008), Filippo Turati giuslavorista. Il socialismo nelle origini del diritto del lavoro, Roma, Bari, Manduria

- Passaniti, Paolo (2011), Il mutuo soccorso nell'ordine liberale. Il sotto-sistema della solidarietà: la legge 3818 del 15 aprile 1886, in: Silei, Gianni (ed.), Volontariato e mutua solidarietà 150 anni di previdenza in Italia, Manduria, Bari, Roma, 63-88

- Persiani, Mattia (2010), Il sistema giuridico della previdenza sociale. Ristampa anagrafica con un saggio introduttivo, Padova

- Procacci, Giovanna (1998), Governare la povertà. La società liberale e la nascita della questione sociale, Bologna

- Ritter, Gerhard (1996), Storia dello Stato sociale, Roma, Bari

- Rizzo, Tito Lucrezio (1988), La legislazione sociale della nuova Italia (1876-1900), Napoli

- Rosanvallon, Pierre (1994), Liberismo, Stato assistenziale e solidarismo, Roma

- Rosselli, Enrico (1950) (ed.), Cento anni di legislazione sociale (1848-1950). Titoli legislativi, Milano

- Rossi, Emanuele, Stefano Zamagni (2011), Introduzione, in: Rossi, Emanuele, Stefano, Zamagni (eds.), Il Terzo settore nell'Italia unita, Bologna

- Rossi, Stefano (2013), Fraternità e mutualismo: forme nuove di un legame antico, in: Diritto pubblico 3, 807-861

- Santoro, Emilio (2013), La povertà nell'era della globalizzazione. Una genealogia dell'arte di governare i poveri, in: Quaderni Fiorentini per la Storia del pensiero giuridico moderno 42, 59-99

- Scaldaferri, Romilda (1986), L'origine dello »Stato sociale« in Italia (1876-1900), in: Il pensiero politico XIX, 2, 223 ss.

- Scaldaferri, Romilda (1986), Tecniche di governo e cultura liberale in Italia. Le origini della legislazione sociale (1879-1885), in: Ricerche di storia politica I, 45 ss.

- Schulze-Delitzsch, Hermann (1871), Delle unioni di credito ossia delle banche popolari di Schulze-Delitzsch. Tradotto per cura dei dottori A. Pascolato e R. Manzato, con Introduzione del Prof. L. Luzzatti, Venezia

- Sellin, Volker (1971), Die Anfänge staatlicher Sozialreform im liberalen Italien, Stuttgart

- Silei, Gianni (2003), Lo Stato sociale in Italia. Storia e documenti, vol. I, Dall’Unità al fascismo (1861-1943), Manduria, Bari, Roma

- Silei, Gianni (2004), Lo Stato sociale in Italia. Storia e documenti, Vol. II, Dalla caduta del fascismo ad oggi (1943-2004), Manduria, Bari, Roma

- Soper, Steven C. (2013), Building a Civil Society. Associations, public life, and the origins of modern Italy, Toronto, Buffalo, London

- Sordi, Bernardo (2014), Selfgovernment, Selbstverwaltung, autarchia: fondali inglesi per scenografie continentali, in: Quaderni Fiorentini per la Storia del pensiero giuridico moderno, Autonomia. Unità e pluralità nel sapere giuridico fra Otto e Novecento 43, 135-163

- Stronati, Monica (2012), Il socialismo giuridico e il solidarismo, in: Enciclopedia Italiana di Scienze, Lettere ed Arti. Il contributo italiano alla storia del pensiero, ottava appendice, Roma, 405 ss.

- Stronati, Monica (2014a), Dalle Società di mutuo soccorso alla Mutua sanitaria integrativa?, in: Non Profit 1, 189-201

- Stronati, Monica (2014b), Una strategia della resilienza: la solidarietà nel mutuo soccorso, in: Scienza \& Politica. Per una storia delle dottrine XXVI, n. 51, dec., 87-100

- Zamagni, Stefano (2012), Prefazione, in: Lippi Bruni, Matteo, Sara Rago, Cristina Ugolini (eds.), Il ruolo delle mutue sanitarie integrative. Le società di mutuo soccorso nella costruzione del nuovo welfare di comunità, Bologna 